\title{
THE FEATURES OF MARKETING COMMUNICATIONS IN THE CONDITIONS OF ECONOMIC CRISIS
}

\author{
JEL̨ENA ŠSALKOVSKA ${ }^{1}$ \\ University of Latvia (Latvia)
}

\begin{abstract}
The article contains the analysis of features of marketing communications of companies in the conditions of economic crisis, when, from one side, the financial capabilities of companies are limited, but, from the other side, this is also the period when the necessity of retaining the market share and changing the strategies of companies' marketing communication increases. The article contains the analysis of the changes in consumers' behaviour in the conditions of crisis. The results of interrogation of representatives of Latvian companies, conducted under the guidance of the author of the article in order to reveal the directions of changes in their marketing strategies in the conditions of crisis, are also analysed in the article.
\end{abstract}

KEY WORDS: marketing communications, marketing communications strategy, integrated approach, crisis, consumers'behaviour.

JEL CODES: M31.

Introduction

In the conditions of economic crisis the companies, operating in the market, need to continue to maintain interrelations with the consumers in order to reveal changes in their demands and their behaviour, as only based on information about these changes it is possible to develop company's marketing communication strategy, corresponding to the changeable marketing environment. In the conditions of economic crisis not only economic factors of consumers' behaviour, but also social, psychological and other factors are exposed to significant changes. Most of consumers start to follow a more rational behaviour stereotype that lead to making more efficient, from consumers' point of view, purchases, i.e., the purchases that enable to maximize consumer's benefit and to minimize his or her expenses that, as a result, lead to the increase of consumer value of purchases. In the condition of crisis consumers tend to minimize the risk, related to the decisions, taken about the purchase, i.e., informational role of marketing communications, as well as the role of credibility of the brand and the company increase. The strategy and content of marketing communications should correspond to the new conditions of consumers' behavior. Nearly in all companies, operating in the market, both planned and forced changes in marketing communications strategy, related to economic crisis, take place.

Research problem, novelty and relevance. The research problem is related to the determination of the features of marketing communications of companies in the conditions of economic crisis, when both consumers' behaviour and the financial capabilities of most of companies change. In this situation the companies face difficulties in determining the directions of adjusting marketing communications to the changeable marketing environment. The novelty of this research is the determination of factual direction of marketing communications strategy of companies - the subjects of Latvian market as well as the analysis of

Jel̦ena Šalkovska - University of Latvia, Economics and Management Faculty (Latvia), M. oec., lecturer. Scientistic interests: marketing.

E-mail: lenand@btv.lv, jelena.salkovska@1u.lv

Tel.: +37129615933. 
correspondence of these changes to the market situation, that is nowadays a very topical issue not only for the Latvian market, but also for the markets of other countries that to a greater or lesser extent experience economic problems.

Research object: marketing communications of Latvian companies in the conditions of crisis.

Research purpose: to analyse the features of marketing communications of Latvian companies in the conditions of crisis, to evaluate the correspondence of their strategy to marketing environment and to develop recommendations, aimed at the improvement of marketing communications in modern economic conditions.

Research tasks:

1. To analyse the changes in consumers' behaviour in the conditions of crisis and to ground the necessity of changes in marketing communications strategy of companies;

2. To analyse the necessary changes in marketing communications strategy in the conditions of crisis that would contribute to the maintenance of company's market position;

3. To ground the methodology and to interrogate marketing specialists of Latvian companies in order to reveal the directions of changes in their marketing communication strategies and to evaluate the correspondence of these changes to economic situation;

4. To develop recommendations for companies, aimed at the improvement of marketing communications in modern economic conditions.

Research methods: abstractive analysis of literature, interrogation.

1. The Change of Consumers' Behaviour in the Conditions of Crisis as the Most Important Factor of Improvement of Marketing Communications of Companies

Nowadays economic situation is the factor that determines the development of marketing communications. However, the influence of the other factors of marketing communications remains significant. The following factors can be emphasized amongst them: the development of science and techniques, the development of new means of marketing communications, globalization processes. Overall marketing environment of companies today is unstable as the result of impact of various factors that impedes marketing communications management, as the consumer constantly corrects his or her behavior, adjusting it to the new conditions. In economic crisis situation the family budget of most of consumers decreases, but, at the same time, their requirements to the quality of goods and services and the content of marketing communications remain high; moreover, the consumers try to make even more efficient purchases.

In the buying process consumer's behaviour is always oriented on getting the maximum consumption value (Kaynama, Smith, 1994; Berger, Nasr, 1998; Bolton, 1998; Rust, Lemon, Zeithaml, 2004). This value is the difference between the consumption benefits and total consumption costs.

Consumption benefits include (Vankatesen, Kumar, 2004):

- Product quality (technical characteristics, design, package etc.);

- Quality of service (guarantees, supply etc.);

- Brand value (placement in the market, prestige etc.);

- Company image in the society (reputation, guarantee of quality etc.).

Total consumption costs include:

- Product purchase price;

- Service price;

- The time, spent for the purchase;

- Product supply costs;

- Other costs (moral, consumption risk etc.). 
Let us assume that a consumer, when choosing a product that he or she needs, compares the alternatives by quality, level of service, brand prestige and company reputation, that shows product recognition by the society. It relates to consumption benefits. However, at the same time the consumer evaluates also possible consumption costs, including the product price, supply costs, the time to be spent for search and evaluation of the product etc. and compares it to his or her budget. This process takes place both in consumption market and business market, taking into account the particularities of consumption benefits and total consumption costs of both markets.

Each company can increase the consumption value, offered in the market, using the following methods:

- First, it can increase consumption benefits, that is, to improve the quality of goods and services, to enhance the brand value and/or company reputation, for example, by offering attractive marketing events in the target market;

- Second, it can reduce total consumption costs, that is, to offer discounts, free supply, to develop and realize the methods of saving consumers' time (Praude, Shalkovska, 2009).

The model of influence of consumers' behaviour to marketing communications strategy of companies is shown in Figure 1:

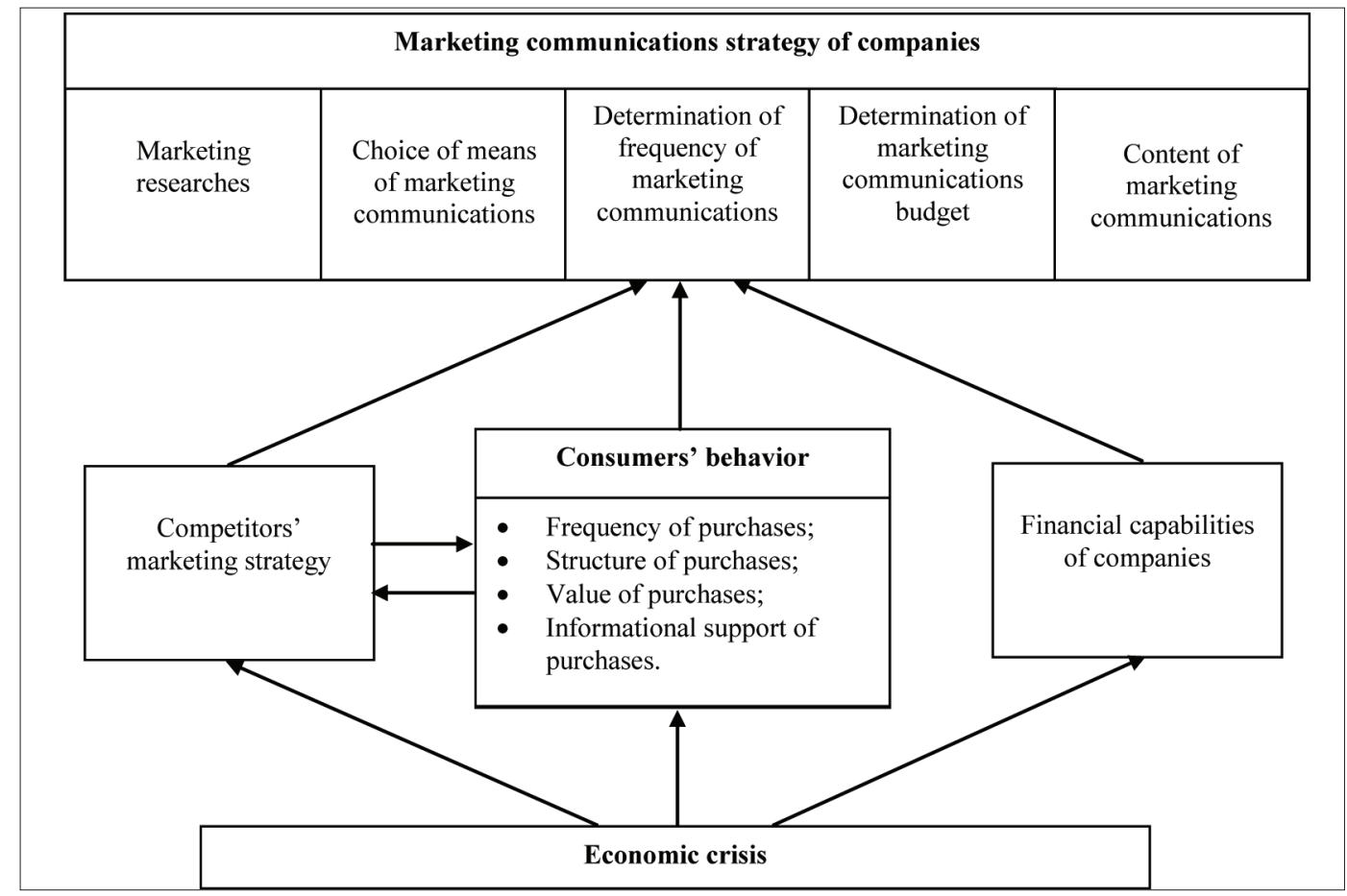

Figure 1. The Model of Influence of Consumers' Behaviour to Marketing Communications Strategy of Companies Source: author.

In the conditions of crisis the following changes of consumers' behavior take place:

1. Tendency to save the family budget even in case the level of incomes of the family members remained the same;

2. The decrease of quantity of the purchased goods and services that influences the aggregated demand in the market;

3. The decrease of frequency of purchase of durable goods and services;

4. Changes in the structure of households' consumption;

5. The decrease of value of each purchase;

6. More grounded choice of goods and services, i.e., the reduction of the number of impulsive; 
7. Purchases and the increase of depth and length of collection of preliminary information on the available alternatives of the goods and services;

8. Changes in the choice of mass media that serve as means of marketing communications, for example, the refuse to purchase some prints and a more frequent use of Internet as a source of information.

Economic crisis is the factor that determines financial capabilities of companies and the ones of the households; consequently, as the result of crisis, changes will occur both in consumers' behaviour and in competitors' marketing strategy. In order to develop marketing communications strategy, the company needs to make appropriate marketing researches that would enable to make an optimal choice of the means of distribution of marketing communications as well as to determine their frequency, budget and content.

In the conditions of crisis the consumers prefer marketing communications that help them to make an efficient choice of a good or service, i.e., provide sufficient information on consumption value. Therefore the companies should change their marketing communications strategy, putting accent on the consumption benefits that are important for the consumer in the conditions of crisis that would enable to maintain and even to enhance the efficiency of marketing communications. The possibility to enhance the efficiency of marketing communications is explained by the fact that the total intensity of marketing communications declines, i.e., the consumers have a less frequent contact with advertisements and other types of marketing communications. In these conditions any marketing message has a higher probability of feedback. The main directions of improvement of companies' marketing communications in the conditions of crisis will be considered below.

\section{The Directions of Improvement of Marketing Communications of Companies} in the Conditions of Crisis

In the conditions of crisis, in spite of limited financial capabilities, the companies should not only to continue to realize communications with the consumers, but also to provide the correspondence of marketing communications to the changes in consumers' behaviour. Therefore the improvement of market communications in the conditions of crisis should meet the following two requirements:

1. Optimality and effective spending of marketing communications budget;

2. Correspondence of the content, frequency and the means of distribution of marketing communications to the new model of consumers' behaviour in the conditions of crisis.

In scope of these requirements the following directions of improvement of marketing communications of companies in the conditions of crisis could be recommended:

- The use of integrated approach to marketing communications (Burnett, 2001; Smith, 2004; Belch, Belch, 2007; Shalkovska, 2008);

- The use of the major and auxiliary means of marketing communications in order to cover different consumers' segments and to minimize expenses as well as the replacement of the main means with cheaper auxiliary means;

- Activation of the use of Internet as a means of distribution of marketing communications (Hanson, 2000; Hanson, Kalyanam 2007);

- Calculation of the minimal efficient frequency of contact with the target audience;

- Emphasizing of cost effectiveness, efficiency and other consumption benefits in the contents of marketing communications.

Integrated marketing communications can be defined as the use of all kinds of marketing communications, coordinating and adjusting them with the other marketing (marketing mix activities) and participants of the market (Praude, Shalkovska, 2005: 44). Integrated approach to marketing communications can be used in order to achieve synergy effect (Ansoff, 1987: 18-72; Novikov, Ribchenko, 2006; Arshinov, Budanov, 2007: 84) from the combination of different types of marketing communications, from carrying 
out mutual marketing campaigns, from the combination of different means of distribution of marketing communications, that would enable to enhance the total final effect of marketing communications and to reduce marketing communications budget per one consumer.

In the process of development and distribution of marketing communications usually 1-2 major means that about one-half of the total budget is spent for are used, as well as a number of auxiliary means, the number of which depend on the coverage of the target audience and the total budget, are applied (Praude, Shalkovska, 2010). The major means of marketing communications can independently and efficiently achieve the objectives of communications and the desired consumers' behaviour. The auxiliary means of marketing communications supplement the major means to enhance the efficiency of communications (Praude, Shalkovska, 2006: 258). In the conditions of crisis it makes sense to put accent on primary use of auxiliary marketing communications, as they enable to save marketing communications budget. However, the analysis of possibility to replace the major means with auxiliary means is mandatory. For example, such replacement will be efficient if a considerable part of the target audience are Internet users (not obligatory active ones), in this case Internet could be well used as an auxiliary means of distribution of communications. The use of auxiliary means is especially efficient in the beginning and in the end of marketing communications campaign before and after the use of major means of distribution of communications (Pelsmacker, Geuens, Bergh, 2007: 73-92).

One more direction of improvement of marketing communications in the conditions of crisis is related to the use of minimal efficient frequency of contact with the target audience. The efficient frequency of marketing communications can be defined as a sufficient number of marketing communication messages to inform each member of the target audience and to cause a feedback (Praude, Shalkovska, 2006: 286). To determine the efficient frequency of marketing communications one should calculate the minimal and maximal necessary frequency. It makes sense to determine the minimal necessary frequency as not all representatives of the target audience will see the first message at once. It is possible that the first marketing communication message they see will be actually the fourth one. The importance of maximal efficient frequency is as follows: if a certain frequency of contacts is exceeded, their efficiency will not only stop exceeding, it will even cause an opposite action. As the result, marketing communications budget is exceeded, but the efficiency of marketing communications declines that is unacceptable in the conditions of crisis.

Activation of the use of Internet as a means of distribution of marketing communications is fully grounded in the conditions of crisis as it enables to reduce marketing communications budget. Marketing communications in Internet have the following advantages:

- Unlimited working time (they are available 24 hours a day 7 days a week).

- It is possible to provide extended information on the product as well as to demonstrate the product's appearance at the same time.

- Easy and fast to replace, it is also possible to have an automated replacement (for example, one banner in the morning and the other one in the evening).

- It enables to reach the target audience that do not use other medias - young people.

- It is possible to aim at some certain target audience (for example, by placing an advertisement in some parts of a homepage, or to show to the registered users only the advertisements that correspond to their interests).

- Appropriate for advertising of trademarks of internationally spread goods.

- Enables to implement widely new communications, messages, ideas, games etc.

- Is suitable for companies' market as it reaches the managers in the middle of the day, when they take decisions, related to the purchase of necessary goods.

- Advertisers can follow the marketing campaign on-line and make changes in case of necessity (Praude, Shalkovska, 2006: 222).

The choice of the specific directions of changes in marketing communications strategy of a company in the conditions of crisis depend on the following factors:

1) The intensity and efficiency of company's marketing communications in pre-crisis period, as the final effect of marketing communications can appear with a delay; 
2) Elasticity of demand for the good, as the demand for prime necessity goods in the conditions of crisis practically remains the same, only the structure of consumption of these goods changes;

3) The correspondence of the elements of company's marketing mix to each other, as in the conditions of crisis any discrepancies of these elements can appear very fast while being passive in pre-crisis period. The consumers change their behaviour in the conditions of crisis, reacting to the conformities and discrepancies of marketing mix elements as they tend to a more efficient choice of goods and services. The elements of marketing mix, corresponding to crisis situation, should be accented in the content of marketing communications.

Further the author of the article will ground the methodology and analyse the results of interrogation of marketing specialists of Latvian companies in order to reveal the directions of changes in their marketing communications strategies ant to evaluate the correspondence of these changes to economic situation.

\section{Research methodology}

In March-April 2011 an interrogation of marketing specialists of Latvian companies was carried out under the guidance of the author in order to reveal the directions of changes in their marketing communications strategies ant to evaluate the correspondence of these changes to economic situation. To make a selection, the quota method was used. The quotation was carried out on the base of company's size, location and sphere of activity. Interrogation was carried out both in big and small companies in 6 Latvian cities: Riga, Jelgava, Liepaja, Ventspils, Valmiera and Daugavpils. The selection scope included 426 companies, functioning in Latvian market. Based on the methodology of Elizabeth Noel, with probability 0.954 we can affirm that the selection is representative. The dependence of selection scope on the general multitude, based on Noel's methodology, is shown in Table 1:

Table 1. Dependence of Selection Scope on the General Multitude

\begin{tabular}{|c|c|c|c|c|c|c|c|c|c|}
\hline Volume of general multitude & 500 & 1000 & 2000 & 3000 & 4000 & 5000 & 10000 & 100000 & $\infty$ \\
\hline Selection scope & 222 & 286 & 333 & 350 & 360 & 370 & 385 & 398 & 400 \\
\hline
\end{tabular}

Source: Noel, 1993: 94.

As we can see in the table, a selection scope of 222 respondents is sufficient for the general multitude of 500 units etc. If we have an endless general multitude then a selection scope of 400 respondents would be sufficient. Therefore we can conclude that after the volume of general multitude achieves a certain level, its further increase does not have any significant impact on the increase of the selection scope.

\section{The Results of Research of Latvian Companies on the Directions of Changes in} their Marketing Communication Strategies in the Conditions of Crisis

Nearly all interrogated marketing specialists $(95 \%)$ mentioned that the behavior of the consumers of their target audience had changed: $54 \%$ of consumers absolutely changed their behaviour and habits while $27 \%$ of consumers changed their behaviour significantly. Marketing specialists explain it with the changes in consumers' incomes and their thinking stereotypes. Due to such significant changes in behaviour of the target audience the companies need to make extended researches of the new demands of the consumers, their preferences and other consumers' characteristics, however, limited financial resources of the companies do not enable to create an appropriate information basis. 
Due to limited financial capabilities $84 \%$ of Latvian companies cut their marketing communications budget in connection with economic crisis: $19 \%$ of companies cut their budget by $75 \%$ and more, $25 \%$ of companies cut their budget by 30-40\% and $40 \%$ of companies cut their budget by $50 \%$ and more. We can conclude that most of Latvian companies in the conditions of crisis are forced to cut their expenses on the account of marketing communications, however, in real life it is realized simply by cutting marketing communications budget while the major approach remains the same, not by enhancing the efficiency of the reduced communications budget that would be more expedient.

A comparative evaluation of the frequency of use of different types of marketing communications by Latvian companies before economic crisis and in economic crisis situation is shown in Table 2.

Table 2. Comparative Evaluation of the Frequency of Use of Different Types of Marketing Communications by Latvian Companies before Economic Crisis and in Economic Crisis Situation

\begin{tabular}{|c|c|c|c|c|c|c|c|c|c|c|}
\hline \multirow[t]{2}{*}{$\begin{array}{l}\text { Types of marketing } \\
\text { communications }\end{array}$} & \multicolumn{5}{|c|}{$\begin{array}{c}\text { Frequency of use of marketing } \\
\text { communications before economic } \\
\text { crisis }\end{array}$} & \multicolumn{5}{|c|}{$\begin{array}{c}\text { Frequency of use of marketing } \\
\text { communications in economic crisis } \\
\text { situation }\end{array}$} \\
\hline & $\sum^{2} \frac{\overline{0}}{2}$ & 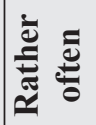 & 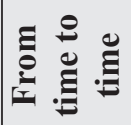 & 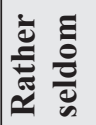 & 㐫 & $\frac{\pi}{0}$ & 㐫 & 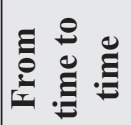 & 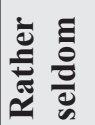 & ל̀ \\
\hline Advertisement & $5 \%$ & $74 \%$ & $21 \%$ & & & & & $39 \%$ & $57 \%$ & $4 \%$ \\
\hline Sales stimulation methods & $18 \%$ & $20 \%$ & $50 \%$ & $12 \%$ & & $16 \%$ & $49 \%$ & $27 \%$ & $8 \%$ & \\
\hline Public relations & $22 \%$ & $19 \%$ & $11 \%$ & $25 \%$ & $23 \%$ & $9 \%$ & $18 \%$ & $13 \%$ & $29 \%$ & $31 \%$ \\
\hline Direct communications & $29 \%$ & $23 \%$ & $18 \%$ & $12 \%$ & $18 \%$ & $45 \%$ & $24 \%$ & $19 \%$ & $12 \%$ & \\
\hline
\end{tabular}

As we can see in Table 2, in economic crisis situation the frequency of use of advertisement considerably decreased (before crisis $79 \%$ of companies often used advertisements, but at the time of crisis $61 \%$ of companies started to use advertisement seldom or even never); the frequency of use of public relations as a type of marketing communications also decreased (instead of $41 \%$ of companies that often used public relations before, now only $27 \%$ of companies use public relations often). The growth of the frequency of use in the conditions of crisis is typical for such types of marketing communications as sales stimulation methods (instead of $38 \%$ of companies that often used sales stimulation methods before, nowadays $65 \%$ of companies often use sales stimulation methods) and direct communications (instead of $52 \%$ of companies that often used direct communications earlier, nowadays $69 \%$ of companies often use direct communications). Such dynamics of change in frequency of use of different types of marketing communications is explained with the fact that companies choose less expensive types of communications. The accent on sales stimulation methods is connected with the features of consumers' behavior in the conditions of crisis as they started to react even more to discounts and other sales stimulation methods. Such dynamics conforms to the present economic situation in the country.

Amongst the means of distribution of marketing communications the following ones are the most popular in the conditions of crisis:

1. Internet - $69 \%$ of companies (before crisis $45 \%$ of companies preferred this means of distribution of marketing communications).

2. Outdoor advertisement - $56 \%$ of companies (before crisis $39 \%$ of companies preferred this means of distribution of marketing communications).

3. Newspapers $-41 \%$ of companies (before crisis $37 \%$ of companies preferred this means of distribution of marketing communications). 
4. Radio $-37 \%$ of companies (before crisis $32 \%$ of companies preferred this means of distribution of marketing communications).

5. TV $-18 \%$ of companies (before crisis $34 \%$ of companies preferred this means of distribution of marketing communications).

Most frequent use of Internet, outdoor advertisement and newspapers is explained with the tendency of companies to save marketing communications budget. $24 \%$ of companies noted that in the conditions of crisis they could even abandon marketing communications at all. Based on the results of interrogation, the rating of criteria of choice of the means of marketing communications by Latvian companies in the conditions of crisis has been made:

1. Minimal total distribution costs $\mathbf{-} \mathbf{7 . 8}$ scores from 10 possible.

2. Maximal coverage of target audience -6.9 scores from 10 possible.

3. Minimal distribution costs per one covered potential buyer -6.2 scores from 10 possible.

From the point of view of the author of the article, even in the conditions of crisis the criterion "minimal distribution costs per one covered potential buyer" should be the most significant one, as this is the case when the most efficient expenditure of marketing communications budget is provided.

In the opinion of the interrogated marketing specialists of Latvian companies, there are the following options to save marketing communications budget while keeping the efficiency of marketing communications in the conditions of economic crisis:

1. To combine different means of marketing communications $-37 \%$ of companies.

2. To cooperate with manufacturers and sellers by carrying out joint mutually beneficial marketing campaigns $-19 \%$ of companies.

3. To cooperate with the competitors by carrying out joint mutually beneficial marketing campaigns $17 \%$ of companies.

4. To combine different types of marketing communications - $15 \%$ of companies.

5. It is impossible $-12 \%$ of companies.

Negative fact is that $12 \%$ of all companies underestimate opportunities to enhance the efficiency of marketing communications by realizing integrated approach and $15 \%$ of companies underestimate the opportunities to enhance the efficiency of marketing communications by combining different types of marketing communications.

One more factor that has a negative impact on the efficiency of marketing communications is the reduction of frequency of pursuance of marketing researches by Latvian companies in the conditions of crisis:

1. Once in a 2-year period - $29 \%$ of companies (before economic crisis $-19 \%$ of companies).

2. Once a year $-53 \%$ of companies (before economic crisis - $48 \%$ of companies).

3. 2-3 times a year $-8 \%$ of companies (before economic crisis $-33 \%$ of companies).

4. Do not conduct marketing researches at all - $10 \%$ of companies (there were no such companies before economic crisis).

The feature of crisis situation is the contradiction: from one side, marketing researches are necessary as consumers' behavior changed and the companies need to investigate it, but from the other side, the companies lack financial resources to conduct researches. It impedes the development of companies' marketing communications strategy.

The forced overall reduction of marketing activity is also a negative factor for the development of companies. For example, the interrogated marketing specialists of Latvian companies think that:

1. Marketing activities considerably decreased in economic crisis situation $-61 \%$.

2. Marketing activities remained on the same level in economic crisis situation $-34 \%$.

3. The use of marketing measures became even more important for the development $o$

4. Companies in economic crisis situation and, therefore, marketing activities increased $-5 \%$. 
In the conditions of overall decrease of marketing activity of the most of companies the intensity of marketing communications also declines, but marketing communications strategy becomes not sufficiently grounded due to the absence of necessary information basis and limited marketing communications budget. Therefore nowadays the existing environment is negative for the development of marketing communications of Latvian companies, however, the companies that are trying to maintain their position in the market, cannot achieve it without marketing communications with the consumers.

\section{Conclusions}

As the result of the conducted research, the following conclusions have been made:

1. Nowadays economic situation is the factor that determines the development of marketing communications. In the conditions of economic crisis the consumers try to make more efficient purchases by trying to increase consumption benefits and to minimize the expenses on consumption of goods and services.

2. In the conditions of crisis the consumers reduce the quantity of purchased goods and services, reduce the frequency of consumption of durable goods and services, change the structure of households' consumption, reduce the value of each purchase as well as make a more grounded choice of goods and services.

3. In the conditions of crisis the consumers prefer marketing communications that help to make an efficient choice of a good or service, i.e., provide sufficient information on consumption value.

4. Nearly all Latvian companies note considerable changes in the behaviour of the consumers of their target audience and acknowledge the importance of conducting marketing researches of the new demands of the consumers; however, they are forced to reduce the intensity of their marketing activity due to limited financial resources.

5. $84 \%$ of Latvian companies cut their marketing communications budget by considerably reducing their expenses on advertisements and public relations and preferring such means of distribution of marketing communications as Internet and outdoor advertisement.

6. Latvian companies use minimization of total expenses on distribution of marketing communications as the main criterion of choice of the means of marketing communications in the conditions of crisis instead the more efficient criterion - minimization of distribution expenses per one potential consumer.

7. Latvian companies underestimate opportunities to use integrated approach to marketing communications as the means to enhance their efficiency and to reduce expenses per one covered representative of the target audience.

8. The choice of the specific direction of changes in company's marketing communications strategy in the conditions of crisis depends on the intensity and efficiency of company's marketing communications in pre-crisis period, on the elasticity of demand for the good and on the correspondence of company's marketing mix elements to each other.

Therefore, nowadays the companies need to put accent on the use of integrated approach to marketing communications, on activation of the use of auxiliary marketing communications, on activation on the use of Internet as a means of distribution of marketing communications and on determination of minimal efficient frequency of contact with the target audience when planning marketing communications. The companies need to change their marketing communications strategy, emphasizing the consumption benefits that are significant for the consumer in the conditions of crisis. These directions of improvement of marketing communications in the conditions of crisis will enable the company to keep its position in the market and to continue its development.

\section{References}

Ansoff, H. I. (1987). Corporate Strategy. New York: McGraw-Hill Education.

Arshinov, V., Budanov, V. (2007). Synergetics at the turn of the 20-21 centuries. Moscow: RSA INION. 
Belch, G., Belch, M. (2007). Advertising and promotion: an integrated marketing communications perspective. Boston: McGraw-Hill/Irwin, p. 130-195.

Berger, P., Nasr, N. (1998). Customer Lifetime Value: Marketing Models and Applications. Journal of Interactive Marketing, Vol. 12(1), p. 18.

Bolton, R. (1998). Dynamic Model of the Duration on of the Customer's Relationship with Contimes Service Provider. Marketing Science, Vol. 17, p. 30-37.

Burnett, J., Moriarti, S. (2001). Marketing communications: an integrated approach. St. Petersburg: Piter, 860 p.

Hanson, W., Kalyanam, K. (2007). Internet Marketing\&e-Commerce. USA: Thomson, p. 176-211.

Hanson, W. A. (2000). Principles of Internet Marketing. South-Western College Publishing, p. 89-125.

Kaynama, S., Smith, L. (1994). Predicting Buying Behaviour from Buyer Intent. Journal of Strategic Marketing, Vol. 2, p. $21-24$.

Noel, E. (1993). Mass Survey. Moscow: AVA-Estra, 195 p.

Novikov, D., Ribchenko, N. (2006). Synergistic effect in the models of distributed control. Available from Internet: $<$ http://econ.asu.ru/lib/sborn/model2006/pdf/17.pdf $>$.

Pelsmacker, P., Geuens, M., Bergh J. (2007). Marketing communications: a European perspective. Harlow [etc.]: Prentice-Hall/Financial Times.

Praude, V., Šalkovska, J. (2005). Mārketinga komunikācijas (Teorija un prakse), 1.sējums. Rīga: Vaidelote, 485 p.

Praude, V., Šalkovska, J. (2006). Mārketinga komunikācijas (Teorija un prakse), 2.sējums. Rīga: Vaidelote, 456 p.

Praude, V., Shalkovska, E. (2009). Marketing factors of formation of company's customer equity. 10th International Conference: Management Horizons in Changing Economic Environment: visions and challenges. Conference Proceedings. Kaunas: European Management Association, Baltic Management Foundation and Vytautas Magnus University, p. 655-667.

Praude, V., Shalkovska, E. (2010). Synergistic Effect in Marketing System. A Journal of the International Institute for General Systems Studies: Scientific Inquiry, No. 11 (1, June), p. 25-34. Available from Internet: http://www.iigss. net/Scientific-Inquiry/June2010/5-Praude_Shalkovska.pdf

Rust, R., Lemon, K., Zeithaml, V. (2004). Return on marketing: Using Customer Equity to Marketing Strategy. Journal of Marketing, Vol. 68 (January), p. 29-33.

Shalkovska, E. (2008). Today's Problems of Companies' Marketing Communications Management. $5^{\text {th }}$ International Scientific Conference "Business and Management'2008” Conference Proceedings. Vilnius, p. 431-437.

Smith, P. R., Taylor, J. (2004). Marketing communications: an integrated approach. London: Sterling, VA: Kogan Page, $696 \mathrm{p}$.

Vankatesen, R., Kumar, V. (2004). A Customer Lifetime Value Framework for Customer Selection and Resource Allocation Strategy. Journal of Marketing, Vol. 68, p. 106-125.

\section{RINKODAROS KOMUNIKACIJOS EKONOMINES KRIZĖS LAIKOTARPIU BRUOŽAI}

JEL̨ENA ŠALKOVSKA

Latvijos universitetas (Latvija)

\section{Santrauka}

Straipsnyje analizuojami organizacijų, veikiančių ekonominès krizès sąlygomis, rinkodaros komunikacijos bruožai, kai, viena vertus, finansiniai organizacijos pajëgumai yra apriboti, kita vertus, šiuo laikotarpiu padidèja poreikis išlaikyti turimą rinkos dali ir keisti organizacijos rinkodaros komunikacijos strategiją. Straipsnyje pateikiama vartotojų elgsenos ekonominès krizės laikotarpiu pokyčiu analizė. Pateikiami autoriaus vykdytos Latvijos organizacijų atstovų apklausos rezultatai, kuriais siekiama parodyti šių bendrovių rinkodaros strategijų pokyčių kryptis esant ekonominei krizei.

PAGRINDINIAI ŽODŽIAI: rinkodaros komunikacija, rinkodaros komunikacijos strategija, integruota prieiga, krize, vartotoju elgsena. 